\title{
Hydraulic conductivity of a dense prehydrated geosynthetic clay liner
}

\author{
F. Mazzieri ${ }^{1}$ and G. Di Emidio ${ }^{2}$ \\ ${ }^{1}$ Assistant Professor, Department SIMAU, Via Brecce Bianche 12, Università Politecnica delle Marche, \\ 60131 Ancona, Italy, Telephone: +39071 2204410, Telefax: +390712204729, \\ E-mail:f.mazzieri@univpm.it (correspondingauthor) \\ ${ }^{2}$ Assistant Professor, Laboratory of Geotechnics, Ghent University, Technologiepark 905, 9052 \\ Zwijnaarde, Belgium, Telephone: +3209 2645720, Telefax: +32092645849, \\ E-mail: gemmina.diemidio@ugent.be
}

Received 3 January 2014, revised 29 July 2014, accepted 9 September 2014

\begin{abstract}
Dense prehydrated geosynthetic clay liners (DPH-GCLs) are a particular type of GCL which, unlike conventional GCLs manufactured with dry bentonite, contain bentonite prehydrated during manufacturing. DPH-GCLs are produced by a patented process that includes bentonite prehydration with a polymer solution and vacuum extrusion. This paper describes the results of permeability tests that were carried out using flexible-wall permeameters to investigate the hydraulic conductivity of a DPH GCL to water, natural seawater and a $12.5 \mathrm{mmol} / 1 \mathrm{CaCl}_{2}$ solution. Moreover, the efficiency of the $0.1 \mathrm{~m}$ overlap seams between DPH-GCL panels has been investigated by means of a medium-scale permeameter able to accommodate specimens $0.305 \mathrm{~m}$ in diameter. Test results showed that the DPH GCL has very low hydraulic conductivity to water $\left(10^{-12}-10^{-11} \mathrm{~m} / \mathrm{s}\right)$ and preserve low permeability, of the order of $10^{-11} \mathrm{~m} / \mathrm{s}$, in the presence of relatively high calcium concentration in the permeating liquid. However, the efficiency of overlap seams can be affected by the permeant type. In the presence of permeant liquids that inhibit swelling (e.g. seawater), the hydraulic efficiency of the seams needs to be improved by adding bentonite paste at the overlap interface. The hydraulic performance of the DPH-GCL is attributed to the combination of prehydration, densification and chemical amendment.
\end{abstract}

KEYWORDS: Geosynthetics, Geosynthetic clay liners, Prehydration, Hydraulic conductivity, Compatibility, Swelling, Overlap seams

REFERENCE: Mazzieri, F. and Di Emidio, G. (2015). Hydraulic conductivity of a dense prehydrated geosynthetic clay liner. Geosynthetics International, 22, No. 1, 138-148.

[http://dx.doi.org/10.1680/gein.14.00037]

\section{INTRODUCTION}

Geosynthetic clay liners (GCLs) are prefabricated hydraulic barriers consisting of a thin layer of unhydrated bentonite ( 5-15 mm) sandwiched between two geotextiles or glued to a polymeric geomembrane. In the last 20 years GCLs have gained wide acceptance in various applications, including bottom liners and cover systems of landfills (Giroud et al. 1997; Li et al. 2002; Cazzuffi and Crippa 2004; Benson et al. 2007; Heerten and Koerner 2008; Scalia and Benson 2011). GCLs offer several advantages over traditional compacted clay liners including cost-effectiveness, ease of installation, limited thickness, low permeability to water (Bouazza 2002) as well as self-healing capacity (Mazzieri and Pasqualini 2000; Babu et al. 2001; Egloffstein 2001; Sari and Chai 2013). GCLs have also found applications in structural waterproofing (Reither and Eichenauer 2002), in linings of artificial ponds and canals (Fleischer and Heibaum 2008) and, more recently, in containment of residues and process liquors from mining applications (Gates et al. 2009; Benson et al. 2010; Bouazza 2010; Hornsey et al. 2010; Shackelford et al. 2010).

The hydraulic efficiency of a barrier system comprised of a GCL as a single liner depends on the low hydraulic conductivity, $k$, attained by the sodium montmorillonite (the main mineral component of bentonite) when permeated with water. Under effective stresses of $10-20 \mathrm{kPa}, k$ is of the order of $10^{-11} \mathrm{~m} / \mathrm{s}$ (Estornell and Daniel 1992; Petrov et al. 1997; Mazzieri and Pasqualini 2000; Shackelford et al. 2000; Jo et al. 2001; Bouazza 2002; Kolstad et al. 2004a; Lange et al. 2007; Meer and Benson 2007).

The low permeability of Na-montmorillonite is associated with 'osmotic swelling', namely the macroscopic expansion of the clay volume as a result of water absorption upon 
hydration (McBride 1994). Most of the water retained by the clay is bound, leaving little pore space available for hydraulic flow and resulting in low $k$ (Jo et al. 2001). In the presence of inorganic electrolyte solutions, osmotic swelling is hindered by high electrolyte concentrations of monovalent cations $(>100 \mathrm{mmol} / \mathrm{l})$ or by moderate concentrations of polyvalent cations $(>25 \mathrm{mmol} / \mathrm{l})$, resulting in increased permeability. In the case of multiple cationic species in solution, the hydraulic conductivity depends both upon the ionic strength of the solution and upon the relative abundance of monovalent and divalent cations (Kolstad et al. 2004a). Organic permeants with low dielectric constants can also cause drastic increases in $k$ of GCLs (Petrov et al. 1997; Mazzieri et al. 2000).

It is widely recognised that prehydration of GCLs with pure water (e.g. deionised or distilled water) or a dilute aqueous solution (e.g. tap water) determines a lower $k$ than the $k$ of non-prehydrated GCLs in direct contact with a given potentially aggressive solution ('first exposure' effect) (Mazzieri et al. 2000; Shackelford et al. 2000; Bouazza 2002; Malusis and McKeehan 2013). However, considering operational conditions in the field, prehydration with unpolluted water cannot always be ensured. One possible means to ensure acceptable performances is to utilise GCLs containing amended or polymer-modified bentonites capable of swelling even in the presence of high electrolyte concentrations (Onikata et al. 1996; Lo et al. 1997; McRory and Ashmawy 2005; Di Emidio 2010; Scalia et al. 2011). Another option is to use special GCLs products, known as dense prehydrated GCLs (DPHGCLs), that are prehydrated during manufacturing through a patented process.

DPH-GCLs were introduced in the 1990s by a British company (Rawell Co., UK) and are currently on the market. The patent registered in the USA is available online (Flynn and Carter 1998). The principle of these products is to confer during manufacturing the benefits of prehydration, chemical amendment and densification to the $k$ of bentonite. Relatively few studies are available in the literature regarding the characteristics and performance of these materials.

This paper presents the results of a research programme carried out jointly at Technical University of Marche (Italy) and at Laboratory of Soil Mechanics of Ghent University (Belgium). In particular, the aim of the study was to illustrate the permeability of a DPH GCL product to water, natural seawater and a $12.5 \mathrm{mmol} / 1 \mathrm{CaCl}_{2}$ solution, and to compare the results with those obtained on conventional GCL, when available. A crucial aspect for the overall efficiency of any GCLs barrier is the efficiency of seams between adjacent panels. Therefore, some of the factors that may impact the efficiency of seams of DPHGCLs such as the confining pressure and the nature of the permeant liquid have been investigated. The practical implications of the experimental findings are discussed.

\section{DENSE PREHYDRATED GCLS}

The reported information regarding the manufacturing process of the DPH-GCL was drawn from the patent
(Flynn and Carter 1998). Dry bentonite clay is first mixed with a solution of water and additives in a high-speed, high-shear mixer. The exact composition of the hydrating solution of the DPH-GCL bentonite is undisclosed, since the patent only reports a range of possible dosages of the different additives. Therefore, it is possible that different production lots have slightly different compositions. The hydrated bentonite is extruded under vacuum into a bentonite sheet about $5.0 \mathrm{~mm}$ thick. The production process induces a densification of the bentonite hydrated core, analogous to the effect of mechanical consolidation (average void ratio $e=1.5$ ), and a nearly parallel alignment of montmorillonite platelets in the sheet plane (Figure 1), which contributes to the particularly low $k$ in the direction normal to the sheet (Egloffstein 1995). Carrier and cover geotextiles are then united to the bentonite and a roll is formed. To prevent dehydration, each roll is wrapped in airtight stretch film.

It is understood from the manufacturer technical information that various DPH GCL products are available, which differ mainly in the geotextile type and mass per unit area whereas the processing of the bentonite core is essentially the same. The different products have different fields of application (structural waterproofing, landscaping, environmental, etc.) and also have different technical specifications (e.g. seaming procedure and overlap width). The seaming procedures of the particular DPH-GCL product used in the study are detailed in the following sections. The readers are warned to consult the technical specifications of each particular product.

Previous studies have reported that DPH-GCLs contain the polymer sodium carboxymethyl cellulose (Na-CMC) and methanol (Kolstad et al. 2004b; Katsumi et al. 2008). These substances have fungicidal and preserving action; moreover, they make the bentonite flexible such that the thin hydrated bentonite sheets can be bent to form rolls (Figure 1) without fissuring (Schroeder et al. 2001). Studies of montmorillonite-Na-CMC mixtures by X-ray diffraction (XRD) and Fourier transform infrared spectroscopy (FTIR) have shown that Na-CMC macromolecules intercalate in the interlayers of montmorillonite, as indicated by the increase of the basal distance, $d_{001}$ (Mitchell 1993 ) of the crystal from 1.25 to $1.47 \mathrm{~nm}$ (Qiu and Yu 2008),

A recent study on the effect of amendment with $\mathrm{Na}$ $\mathrm{CMC}$ on the characteristics of a sodium bentonite has shown an increase in the swelling capacity and a reduction of the $k$ of treated bentonite clay (known as HYPER clay) in comparison with the untreated bentonite in the presence of various permeant solutions (Di Emidio 2010). The reduction in $k$ can be ascribed to the intercalation of strongly hydrophilic Na-CMC molecules, which increase the water adsorption and retention capacity of the clay (McBride 1994).

Possible components of the hydrating solution mentioned in the patent are sodium hexametaphosphate and sodium polyacrylate. Hexametaphosphate and polyphosphate anions are known to impart a dispersing action on clay suspensions by preferentially absorbing to the exposed aluminium cations at the edge of clay platelets, 


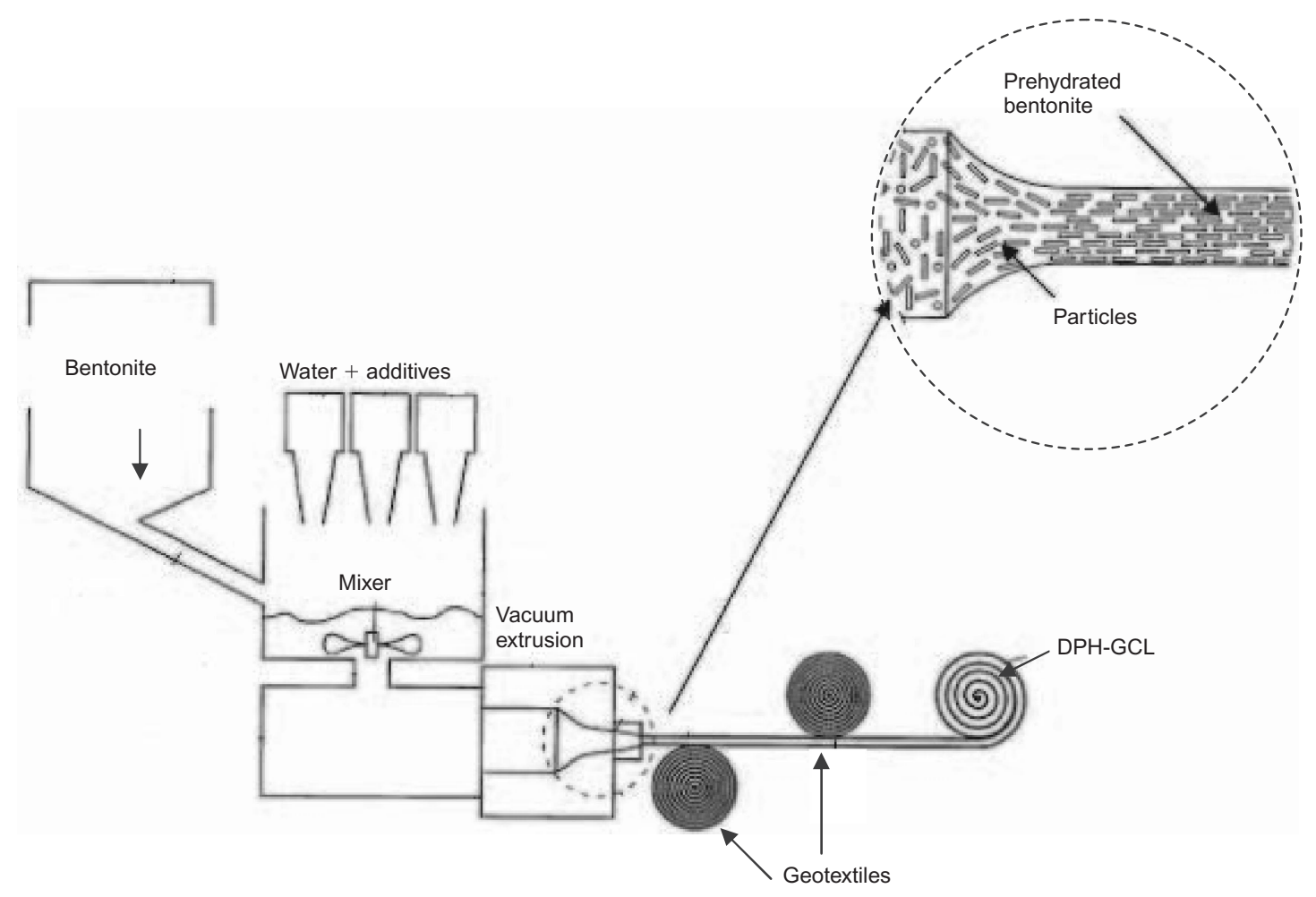

Figure 1. Manufacturing of DPH-GCLs (modified after Flynn and Carter (1998))

preventing edge-to-face aggregations. Polyacrylate polymers possess water-absorbency properties that are similar to those of Na-CMC (Qiu and Yu 2008) and are utilised in other polymer-amended clays (Scalia et al. 2011). Coating of the solid surfaces with $\mathrm{Na}-\mathrm{CMC}$ or polyacrylates may prevent conversion of treated bentonite into calcium or other multivalent cations form (Flynn and Carter 1998). Moreover, excess dispersant anions may bind to cations in the pore water, thus reducing or retarding the interaction with the charged surface (e.g. cation exchange). It is well known that the latter process can affect the overall performance of the bentonite as a hydraulic barrier (e.g. Lin and Benson 2000; Mazzieri and Pasqualini 2000). In this regard, addition of salts and polymers in their sodium form probably contributes to enrichment in sodium of the clay exchange complex.

A few studies in the literature have investigated the permeability of materials identified as 'factory-prehydrated' or 'dense prehydrated' GCLs. In the first study (Schroeder et al. 2001), permeability tests were performed in a rigid-wall apparatus, using various permeant liquids (standard water, $\mathrm{CaCO}_{3}$-saturated water, seawater, landfill leachate) under different vertical effective confining stress $\left(\sigma_{\mathrm{v}}^{\prime}\right)$. The measured $k$ values were always lower than $5.0 \times 10^{-11} \mathrm{~m} / \mathrm{s}$, even under the lowest confining stress adopted in the study $\left(\sigma_{\mathrm{v}}^{\prime}=3.8 \mathrm{kPa}\right)$. Moreover, specimens simulating actual overlap seams (with and without the addition of supplemental bentonite paste in the overlap) were permeated with standard water (made of $25 \%$ distilled water and $75 \% \mathrm{CaCO}_{3}$-saturated water). Schroeder et al. (2001) did not report the overlap width they tested but stated that standard conditions recommended for joints were adopted. They also reported that the permeability of overlap specimens (with and without bentonite paste) was practically the same as that of singlelayers specimens.

Kolstad et al. (2004b) reported the $k$ of a DPH-GCL permeated with deionised water (DI), and with aqueous solutions containing $1 \mathrm{~mol} / 1 \mathrm{NaCl}, 1 \mathrm{~mol} / 1 \mathrm{CaCl}_{2}, \mathrm{HCl}$ $(\mathrm{pH}=1.2)$ and $\mathrm{NaOH}(\mathrm{pH}=13)$. The tests were conducted in flexible-wall permeameters at an average isotropic effective stress, $\sigma_{\mathrm{i}}^{\prime}=20 \mathrm{kPa}$. The measured $k$ values were always lower than $1.0 \times 10^{-11} \mathrm{~m} / \mathrm{s}$, except for the $\mathrm{HCl}$ solution for which $k$ was equal to $1.6 \times 10^{-10} \mathrm{~m} / \mathrm{s}$.

Katsumi et al. (2008) conducted permeability tests for up to 5 years using flexible-wall permeameters $\left(\sigma_{\mathrm{i}}^{\prime}=25 \mathrm{kPa}\right)$ to investigate the performance of a DPH-GCL and found $k<5.0 \times 10^{-12} \mathrm{~m} / \mathrm{s}$ for electrolyte solutions with concentrations of up to $1 \mathrm{~mol} / 1 \mathrm{CaCl}_{2}$. Mazzieri et al. (2013) permeated a DPH-GCL in two stages: the first was carried out with distilled water (DW), the second was carried out with a synthetic solution having $\mathrm{pH}=2.0$ and containing $\mathrm{Cu}^{2+}, \mathrm{Zn}^{2+}$ and $\mathrm{Pb}^{2+}$, each at concentrations equal to $25 \mathrm{mmol} / \mathrm{l}$. The $k$ to DW was $3.7 \times 10^{-12} \mathrm{~m} / \mathrm{s}$ and increased to $1.3 \times 10^{-11} \mathrm{~m} / \mathrm{s}$ upon permeation with the synthetic solution. In short, the available experimental data, based on laboratory studies, indicate that DPH-GCL products may be able to maintain very low permeability in the short-term, even in the presence of permeant solutions that have been proven to increase the permeability of conventional GCLs.

One of the most critical issues related to field performance of conventional GCLs is desiccation, which has been shown to impair the hydraulic performance if combined with cation exchange (Lin and Benson 2000; Meer and 
Benson 2007). The manufacturer claim that DPH-GCLs will not desiccate in the field as they are highly hydrophilic and that once in the ground they will suck up moisture from the surrounding soil or concrete. The issue of desiccation of the same DPH-GCL product used in the present study was addressed in two laboratory studies. In the first (Mazzieri and Pasqualini 2008) dry-wet cycles were simulated by repeatedly drying the DPH-GCL in an oven at $35^{\circ} \mathrm{C}$ and rehydrating the DPH-GCL using DW or a calcium solution $\left(12.5 \mathrm{mmol} / 1 \mathrm{CaCl}_{2}\right)$. Dry-wet cycles using DW had little or no effect on the $k$ of the DPH-GCL product. Combination of desiccation and permeation with the calcium solution eventually resulted in a drastic increase in $k$. The increase was ascribed to the presence of desiccation cracks that did not heal upon rehydration. However, the simulated drying conditions were very severe (water content, $w$, equal to $5-10 \%$ in the dry stages) and probably unlikely to occur in the field. In the second study (Mazzieri et al. 2009) dry-wet cycles with milder desiccation states ( $w$ ranging from 85 to $35 \%$ in the dry stages) were simulated with a $12.5 \mathrm{mmol} / 1 \mathrm{CaCl}_{2}$ solution being used as permeant liquid. The $k$ of the DPH-GCL remained relatively low $\left(\leqslant 2.0 \times 10^{-11} \mathrm{~m} / \mathrm{s}\right)$ for $w \geqslant 45 \%$. For $w=35 \%$ the $k$ increased irreversibly. Unhealed cracks were responsible for the increase in $k$. From a practical point of view, the test results indicated that the response of the DPH-GCL product to dry-wet cycles depends upon the permeant liquid and the extent of desiccation. Therefore, more focus is necessary in order to assess the extent of desiccation that DPH-GCL products may encounter in typical applications. At present, the writers are not aware of any published study that addresses the DPH-GCLs long-term field behaviour, in which samples from actual installations were examined. Several cases of application, including a landfill base liner, are listed in the manufacturer's website. According to the manufacturer, no leaks have been reported.

\section{MATERIALS AND METHODS}

\subsection{GCLs}

The DPH-GCL product used in this study is recommended by the manufacturer primarily for waterproofing of structures where an oversite blinding has been specified. The product has a high-strength woven polypropylene cover geotextile (average mass per unit area $119 \mathrm{~g} / \mathrm{m}^{2}$ ) and a perforated polyester scrim carrier geotextile (average mass per unit area $17 \mathrm{~g} / \mathrm{m}^{2}$ ), which presents large voids (about $1 \mathrm{~mm}$ in diameter), through which prehydrated bentonite can be seen. The geotextiles are united to the bentonite by simply pressing them against the bentonite (no glue or reinforcement connecting the geotextiles is present). Therefore, although no direct assessment was carried out in this study, the internal shear strength of this product is expected to be low. In the as-manufactured state, bentonite is sufficiently hard to resist extrusion through the voids of the geotextile, even if walked on by workers during installation.

The standard rolls of the product used in this study are $1 \mathrm{~m} \times 5 \mathrm{~m}$ in size, but larger sizes are possible. The manufacturer's specifications state that the rolls are wrapped in airtight stretch films and packaged into boxes containing 20 rolls each. The boxes are sealed with polyethylene covers for weatherproofing. The manufacturer's specifications suggest that the surface onto which the product is to be laid should be smooth concrete, free from abrupt irregularities with all lumps removed and voids filled with mortar or bentonite paste. The product should be laid with the nonwoven perforated scrim geotextile in contact with the blinding concrete and with the woven geotextile uppermost. The manufacturer recommends placing a $50 \mathrm{~mm}$ concrete blinding to protect the GCL from the steel fixers and inclement weather.

In Table 1 the main physical and chemical properties of the DPH-GCL product used in this study are listed together with the properties of a conventional needle-punched GCL (C-GCL) used for some comparative testing. The swell index of the DPH-GCL is less than the C-GCL. However, the traditional swell index test (ASTM D5890) does not fully reflect the swelling behaviour of DPH-GCLs; firstly, because the clay must be oven dried before testing, secondly, because the presence of polymers may interfere with the settling of the clay and thus affect the test results (Di Emidio 2010). The swelling test cylinders were left standing longer than specified in the test methods $(24 \mathrm{~h})$; however, no significant increase in the free swell of the DPH-GCL was observed.

In Figure 2 the diffraction spectra of the air-dried powdered clays from the two GCLs are shown. The basal

Table 1. Physical and chemical properties of the C-GCL and DPH-GCL products used in this study

\begin{tabular}{|l|c|c|c|}
\hline Property & C-GCL & DPH-GCL & Note \\
\hline Mass per unit area of bentonite $M_{\text {bent }}\left(\mathrm{g} / \mathrm{m}^{2}\right)$ & 4390 & 5430 & ASTM D5993 \\
Cover geotextile & PP B NW T & PP W & \\
Carrier geotextile & PP PS & \\
Average thickness (mm) & 6.4 & 5.4 & ASTM D2216 \\
Bentonite water content, $w(\%)$ & 10 & 42 & XRD \\
Principal mineral & Montmorillonite $(89 \%)$ & Montmorillonite (97\%) & ASTM D5890 \\
Swell index $(\mathrm{ml} / 2 \mathrm{~g})$ & 36 & $2.3^{\mathrm{b}}$ & ASTM D854 \\
Specific gravity, $G_{\mathrm{s}}(-)$ & 2.65 & 2.56 & \\
\hline
\end{tabular}

a B, impregnated with bentonite powder; NW, nonwoven; PE, polyester; PP, polypropylene; PS, perforated scrim; T, thermally treated; W, woven.

${ }^{b}$ The separation surface was not clearly identifiable due to turbidity of the solution; the reported value is the average of three measurements. 


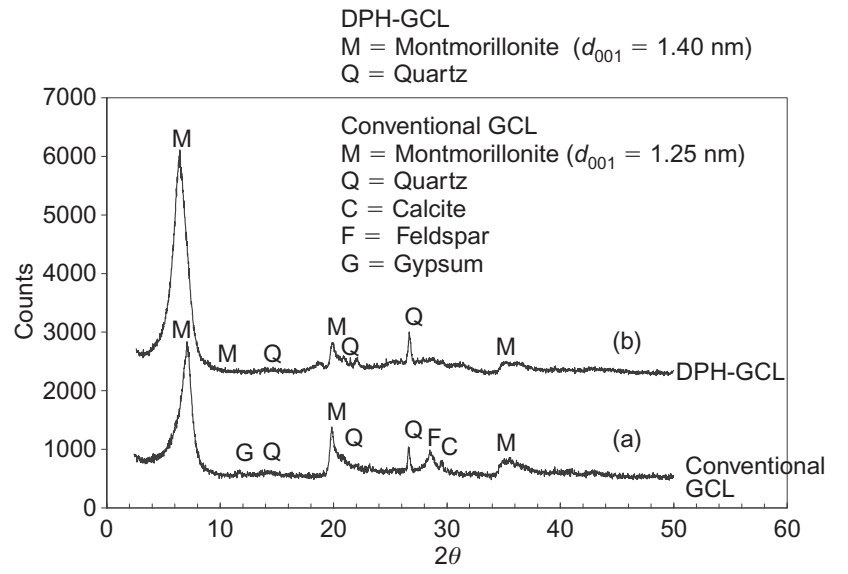

Figure 2. XRD spectra of air-dried powdered bentonites: (a) C-GCL; (b) DPH-GCL

distance of montmorillonite crystals of C-GCL was $1.25 \mathrm{~nm}$, typical of sodium montmorillonite. The basal distance of DPH-GCL bentonite was $d_{001}=1.40 \mathrm{~nm}$. The increase in the basal distance of montmorillonite can be ascribed to the intercalation of polymer molecules in the interlayer (Qiu and Yu 2008).

As recommended in the technical specification sheets of the DPH-GCL product used in this study, the seams are obtained by overlapping the edges of the adjacent panels for at least $0.10 \mathrm{~m}$. The overlap zone is marked by a red line printed on the woven geotextile, which must be installed facing upwards. According to technical specification, the openings in the perforated scrim allow the bentonite to swell out upon wetting and to seal the interface.

The suggested minimum overlap width of this product $(0.10 \mathrm{~m})$ is less than the range commonly recommended for conventional GCLs $(0.15-0.3 \mathrm{~m})$. The motivation probably resides in the type of application recommended for this product: in waterproofing of structures large deformation of the subgrade that may cause panel separation are not expected (as opposed, for example, to landfill covers). Moreover, GCLs installed under structures are less exposed to dry-wet cycles, which may cause shrinking (Thiel et al. 2006; Rowe et al. 2010) and separation of conventional GCLs panels (Koerner and Koerner 2005a, 2005b; Thiel and Richardson 2005). To improve the sealing of seams or to seal pipe penetrations, the manufacturer recommends a bentonite paste (mastic) with composition similar to the bulk DPH-GCL but with a higher water content (144\%), which enables spreading of the paste on the overlap edges and around pipe penetrations. The manufacturer states that for applications where an immediate seal against hydrocarbons, contaminants or gases is required, a liberal application of bentonite mastic must be made to the woven geotextile prior to lapping. Thus, the need for bentonite paste must be assessed on a case-by-case basis depending on the permeant fluid to be contained.

\subsection{Permability tests}

Permeability tests on single-layer GCL (i.e. no overlap) were carried out in flexible-wall permeameters accommodating $0.10 \mathrm{~m}$ diameter specimens, in general agreement with ASTM D5084 (except for the limitations on the applied hydraulic gradient, which was usually higher than recommended in the test method). A constant average isotropic effective stress $\left(\sigma_{\mathrm{i}}^{\prime}\right)$ was maintained during the test. Tests were performed at different stress levels $(14,27$ and $275 \mathrm{kPa}$ ). The permeant liquids used were DW, natural seawater (NSW) and a $12.5 \mathrm{mmol} / \mathrm{CaCl}_{2}$ solution. The chemical composition of the NSW used in this study is described in Table 2.

Permeability tests on the overlaps were carried out in a medium-scale flexible-wall permeameter able to accommodate circular specimens $0.305 \mathrm{~m}$ in diameter and to conduct two separate tests simultaneously, although subjected to the same cell pressure (Figure 3a). The DPHGCL seams were simulated by overlapping two specimens $0.305 \mathrm{~m}$ in diameter, shaped as circular segments (Figure $3 b)$. The resulting overlap section was $0.1 \mathrm{~m}$ in width and shaped as a double-based circular segment, whereas an actual overlap section is of rectangular shape. To have a uniform thickness of the testing layout and to allow hydraulic flow, the removed portions of the DPH GCL were replaced by nonwowen geotextile layers (Figure 3a). The geotextiles were wetted prior to the test assembly to promote saturation.

Four permeability tests (two pairs) on the overlaps were performed. Tests were conducted in pairs, as the mediumscale permeameter allows conducting two tests simultaneously and using different permeant liquids, if desired. The first test pair was conducted without bentonite paste on the overlap, using DW and NSW as permeant liquids, respectively. To examine the effect of the confining stress on the seam efficiency, the isotropic effective stress $\sigma_{\mathrm{i}}^{\prime}$ was applied in four stages of $14,28,55$ and $110 \mathrm{kPa}$, respectively. The minimum applied effective stress $(14 \mathrm{kPa})$ was selected to simulate conditions where the GCL is placed under relatively thin cover layers (soil or concrete), whereas the maximum applied effective stress $(110 \mathrm{kPa})$ depends on the allowable cell pressure of the medium-scale apparatus.

The second test pair was conducted to investigate the effect of bentonite paste on the overlap. In the absence of precise specifications, a $1 \mathrm{~mm}$ thick layer was applied on each side of the overlaps, $1 \mathrm{~mm}$ being considered to be the minimum layer of bentonite paste that could be applied

Table 2. Chemical composition of the NSW

\begin{tabular}{|c|c|c|c|c|c|c|c|c|c|c|c|}
\hline Ion/parameter & $\begin{array}{c}\mathrm{Na}^{+} \\
(\mathrm{mmol} / \mathrm{l})\end{array}$ & $\begin{array}{c}\mathrm{K}^{+} \\
(\mathrm{mmol} / \mathrm{l})\end{array}$ & $\begin{array}{c}\mathrm{Ca}^{2+} \\
(\mathrm{mmol} / 1)\end{array}$ & $\begin{array}{c}\mathrm{Mg}^{2+} \\
(\mathrm{mmol} / \mathrm{l})\end{array}$ & $\begin{array}{c}\mathrm{Cl}^{-} \\
(\mathrm{mmol} / \mathrm{l})\end{array}$ & $\begin{array}{c}\mathrm{SO}_{4}^{2-} \\
(\mathrm{mmol} / 1)\end{array}$ & $\begin{array}{l}\mathrm{HCO}_{3}^{-} \\
(\mathrm{mmol} / \mathrm{l})\end{array}$ & $\begin{array}{c}\mathrm{CO}_{3}{ }^{2-} \\
(\mathrm{mmol} / \mathrm{l})\end{array}$ & $\begin{array}{c}\mathrm{NO}_{3}^{-} \\
(\mathrm{mmol} / \mathrm{l})\end{array}$ & $\begin{array}{l}\mathrm{pH} \\
(-)\end{array}$ & $\begin{array}{c}\mathrm{EC} \\
(\mathrm{S} / \mathrm{m})\end{array}$ \\
\hline Concentration/ value & 501 & 11.5 & 10.6 & 49 & 547 & 26.8 & 2.7 & 0.3 & 0.7 & 7.9 & 5.5 \\
\hline
\end{tabular}




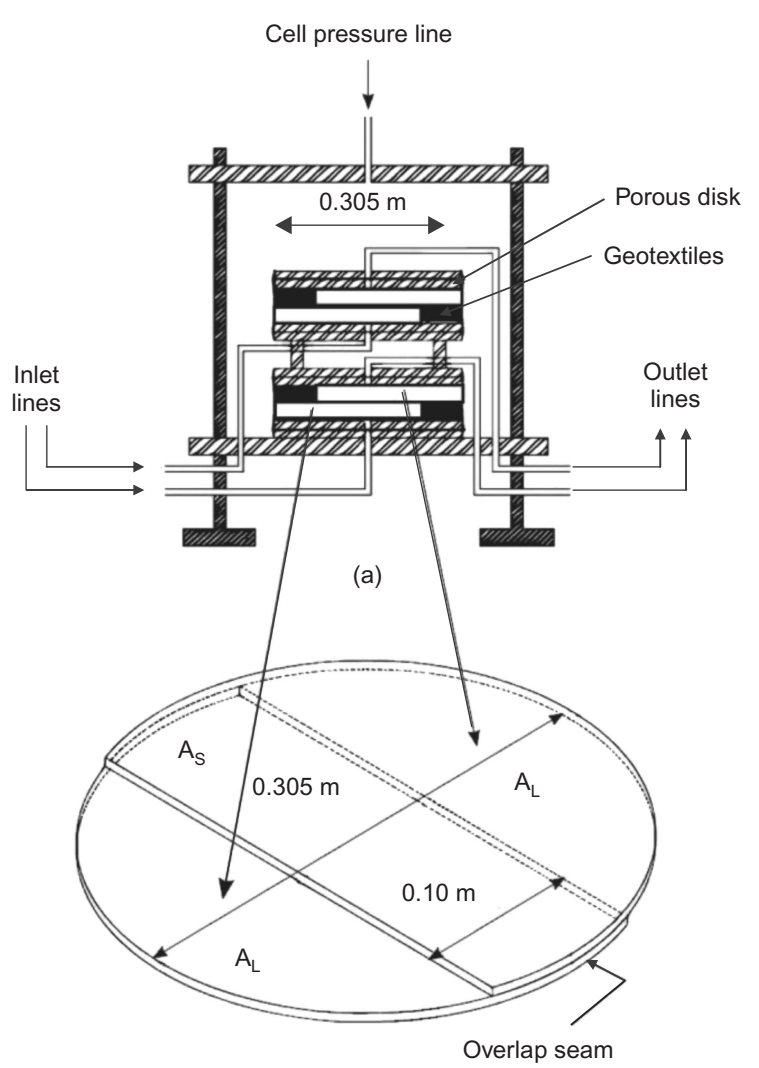

(b)

Figure 3. (a) Medium-scale flexible-wall permeameter.

(b) Layout of permeability tests on overlap seams. $A_{\mathrm{s}}$, area of the two-layers central portion of the overlap $\left(0.0278 \mathrm{~m}^{2}\right)$; $A_{\mathrm{L}}$, area of the single-layer lateral portions of the overlap $\left(0.0226 \mathrm{~m}^{2}\right)$

uniformly on the overlap. The bentonite paste was spread with a spatula and the obtained thickness was measured by a caliper. The average $\sigma_{\mathrm{i}}^{\prime}$ was equal to $14 \mathrm{kPa}$ throughout the test; the permeant liquids used were DW and NSW, respectively.

\section{RESULTS AND DISCUSSION}

\subsection{Permeability to water}

Figure 4 illustrates the trend of $k$ versus time of DPHGCLs specimens permeated with DW under different $\sigma_{\mathrm{i}}^{\prime}$ (14, 27 and $275 \mathrm{kPa})$. All tests were permeated for a longer time than required to meet the termination criteria as per ASTM D5084. As expected, the value of $k$ decreased with increasing $\sigma_{\mathrm{i}}^{\prime}$. In particular, the $k$ values were consistently lower than $10^{-11} \mathrm{~m} / \mathrm{s}$. The graph of $k$ plotted against time of a $\mathrm{C}$-GCL specimen permeated at average $\sigma_{\mathrm{i}}^{\prime}$ equal to $27 \mathrm{kPa}$ is also displayed in Figure 4 for comparison. For the given effective stress, the $k$ of the C-GCL $\left(1.5 \times 10^{-11} \mathrm{~m} / \mathrm{s}\right)$ was about four times higher than the DPH-GCL $\left(3.7 \times 10^{-12} \mathrm{~m} / \mathrm{s}\right)$. The lower permeability to water of the DPH-GCL relative to the C-GCL results from a combination of factors: the densification of bentonite through the vacuum extrusion process, the presence of additives and polymers as well as the higher mass of bentonite per unit area (Table 1).

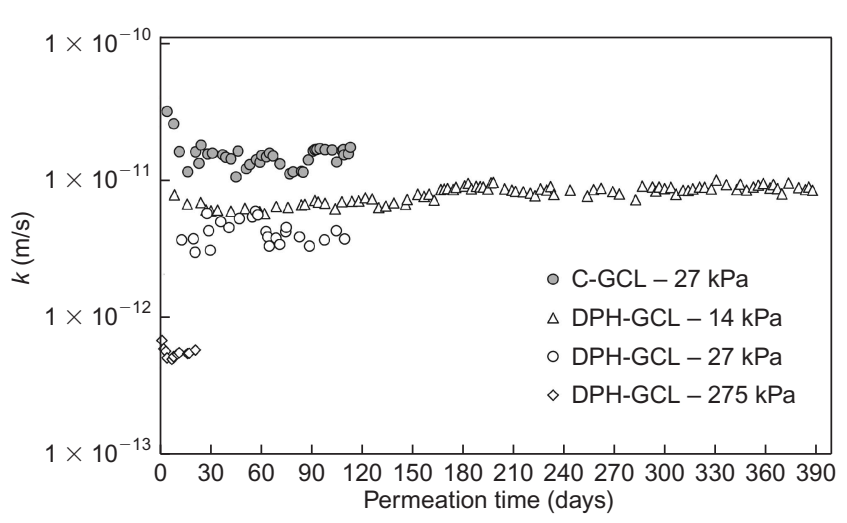

Figure 4. Hydraulic conductivity of the DPH-GCL and of the C-GCL permeated with DW under different confining effective stress

The test conducted at the lower effective stress, which displayed the highest $k\left(\sim 8 \times 10^{-12} \mathrm{~m} / \mathrm{s}\right)$ and allowed a sufficient amount of fluid to be collected, was continued up to about 400 days to characterise the effluent liquid. Samples were regularly collected over time and analysed for electrical conductivity (EC), $\mathrm{pH}$ and major dissolved cations $\left(\mathrm{Na}^{+}, \mathrm{Ca}^{2+}\right)$ and anions $\left(\mathrm{Cl}^{-}, \mathrm{SO}_{4}{ }^{2-}\right)$. The trends of measured EC and of the concentrations of major dissolved ions in the effluent liquid are illustrated in Figure 5. The measured data have been plotted against the number of pore volumes of flow. Sodium $\left(\mathrm{Na}^{+}\right)$was the most abundant cation in the effluent liquid, as indicated also by the similarity of the plots representing EC and sodium concentration. Significant concentrations of chloride $\left(\mathrm{Cl}^{-}\right)$and sulfate $\left(\mathrm{SO}_{4}{ }^{2-}\right)$ were measured. However, the sum of equivalent concentration of chloride and sulfate did not balance the cation equivalent concentration. To preserve the electroneutrality of the effluent solution, additional anions must have been present, most probably phosphate, added as phosphate salts in the prehydration solution. Although total phosphate was not measured during this specific test, significant concentrations (up to $600 \mathrm{mg} / \mathrm{l}$ ) were detected in the effluent liquids of other permeability tests performed with the same DPH-GCL product. At the average $\mathrm{pH}$ values measured in the effluent

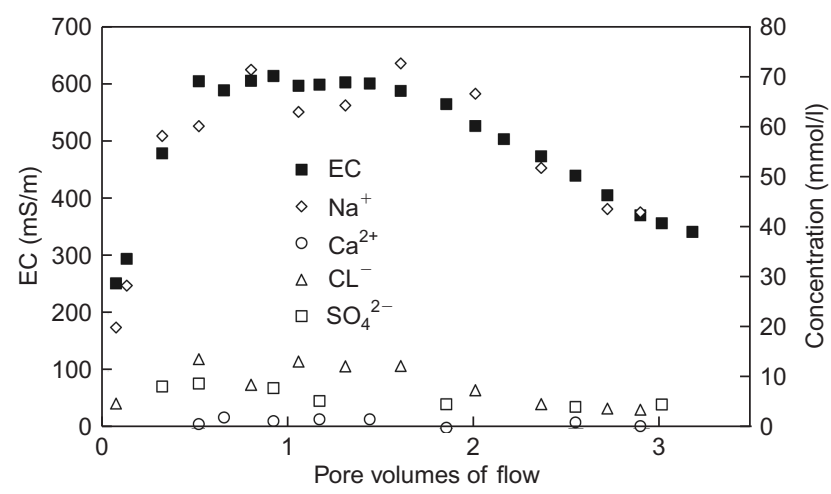

Figure 5. Electrical conductivity (EC) and concentrations of major dissolved ions in the effluent liquid during permeation of the DPH-GCL with DW, plotted against the number of pore volumes (test in flexible-wall permeameter, $\sigma_{\mathrm{i}}^{\prime}=14 \mathrm{kPa}$ ) 
liquid $(\mathrm{pH} \sim 6.5)$, phosphate is present as $\mathrm{H}_{2} \mathrm{PO}_{4}^{-}$ $(\sim 75 \%)$ and $\mathrm{HPO}_{4}{ }^{2-}(\sim 25 \%)$.

\subsection{Permeability to NSW}

Waterproofing to NSW using GCLs requires the assessment of the impact of permeation of the GCL with NSW. Figure 6 illustrates the results of permeation tests of the C-GCL and the DPH-GCL with NSW. Upon direct permeation with NSW the C-GCL displayed very high $k$ $\left(10^{-7}-10^{-8} \mathrm{~m} / \mathrm{s}\right)$, in agreement with other studies (Shan and Lai 2002). Despite the predominance of sodium cations in NSW (Table 2), the ionic strength inhibits swelling of bentonite and the resulting $k$ is very high (Kolstad et al. 2004a).

It is widely recognised that needle-punched fibres restrict swelling of bentonite hydrated with water at low confining stresses and that GCLs with intact fibres will generally have a lower $k$ to water than without fibres (e.g. Petrov et al. 1997; Lake and Rowe 2000). However, in the case of poor bentonite swelling, bundles of fibres in needle-punched GCLs may not be efficiently impregnated by swollen bentonite and represent preferential flow pathways (Scalia and Benson 2011). Therefore, the test was repeated on a fibre-free specimen prepared with the same bentonite as the C-GCL and the same nominal mass of bentonite per unit area as the commercial product. The permeability of the fibre-free specimen was indeed lower $\left(10^{-9} \mathrm{~m} / \mathrm{s}\right)$ but still relatively high for a barrier function. A similar fibre-free specimen was first hydrated and permeated with tap water ('prehydration') and then with NSW. The $k$ to NSW of the prehydrated specimen $\left(10^{-10} \mathrm{~m} / \mathrm{s}\right)$ was of about one order of magnitude lower than the nonprehydrated specimen, as a result of the well-known 'first exposure' effect (Shackelford et al. 2000). It should be noted that a fibre-free specimen was used only for comparison purpose. A GCL with intact fibres, hydrated with water, would give a lower permeability than a fibre-free GCL during the water permeation stage and probably during the permeation stage with NSW as well.

The $k$ of the DPH-GCL directly permeated with NSW was extremely low $\left(1.6 \times 10^{-12} \mathrm{~m} / \mathrm{s}\right)$. This result can be ascribed to the combined effect of prehydration, densification and chemical amendment. Although the DPH-GCL was permeated for more than 6 months, due to the low

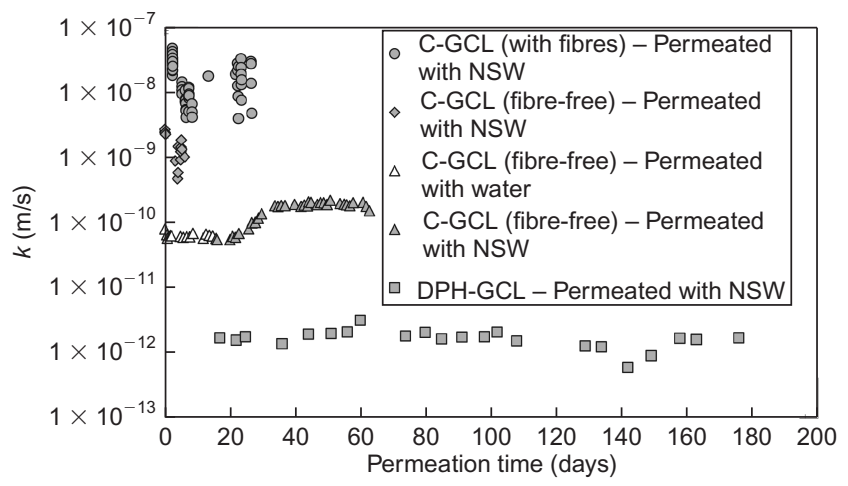

Figure 6. Hydraulic conductivity of the C-GCL, of bentonite specimens without fibres and of the DPH-GCL permeated with NSW (tests in flexible wall permeameter, $\sigma_{\mathrm{i}}^{\prime}=14 \mathrm{kPa}$ ). permeability only 1.2 pore volumes of flow were permeated. However, permeability tests with a duration of more than 5 years (corresponding to approximately 18 pore volumes of flow) and using strong electrolyte solutions showed no significant increases in the laboratory-measured long-term $k$ of a similar DPH-GCL product (Katsumi et al. 2008).

\subsection{Permeability to $12.5 \mathrm{mmol} / \mathrm{L} \mathrm{CaCl}_{2}$}

The trend of $k$ plotted against time for permeation with $12.5 \mathrm{mmol} / 1 \mathrm{CaCl}_{2}$ is illustrated in Figure 7. A $12.5 \mathrm{mmol} / 1 \mathrm{CaCl}_{2}$ solution has been used in other studies on GCLs to simulate a calcium-rich permeant liquid (Benson et al. 2007). The DPH-GCL was continuously permeated for more than 5 years (1825 days) with the calcium solution. No appreciable increase in $k$ was observed.

Benson et al. (2007) conducted a permeability test on a non-prehydrated conventional GCL (different from the product used in the present study) using a $12.5 \mathrm{mmol} / \mathrm{l}$ $\mathrm{CaCl}_{2}$ solution. The applied stress and hydraulic gradient were very similar to those applied in the present study on the DPH-GCL. A gradual increase in $k$ of the conventional GCL, starting from about 300 days of permeation was observed. The increase in $k$ was ascribed to the progressive cation exchange of sodium adsorbed to the bentonite surface for calcium cations. As the exchange rate is controlled by diffusion of calcium cations in the interlayer, for relatively dilute solutions such as the one used in the study, the concentration gradient driving the diffusion was low and the induced exchange process relatively slow. The $k$ stabilised after about 600 days of permeation to $2.3 \times 10^{-10} \mathrm{~m} / \mathrm{s}$, compatible with a calcium-exchanged bentonite.

The difference between the DPH-GCL and the conventional GCL is ascribed firstly to the lower $k$, which reduces the amount of calcium cations entering the DPH-GCL by advection. Secondly, the presence of various sodium-rich additives contributes to increasing the sodium concentration in pore water (Figure 5), which makes cation exchange of sodium for calcium less favoured. Phosphate anions present in the porewater of the DPH-GCL may also remove part of the calcium cations by precipitation of insoluble compounds. Finally, polymers added to the clay

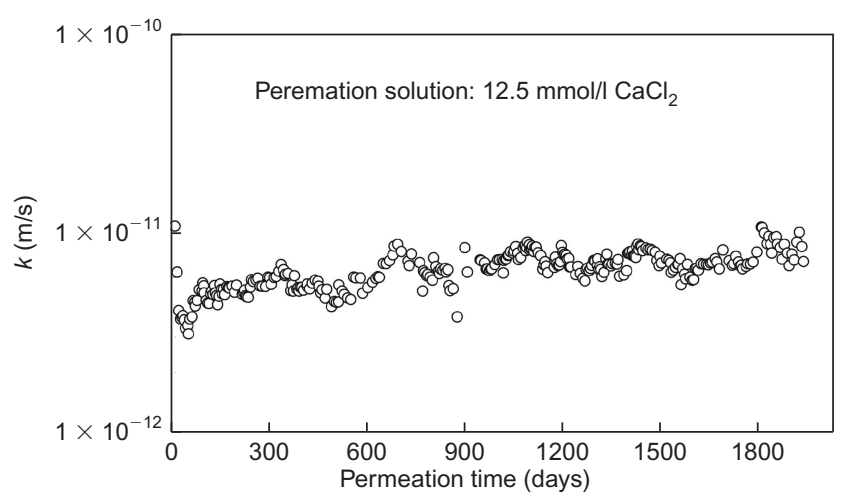

Figure 7. Hydraulic conductivity of the DPH-GCL permeated with a $25 \mathrm{mmol} / \mathrm{l} \mathrm{CaCl}_{2}$ solution (test in flexible-wall permeameter, $\sigma_{\mathrm{i}}^{\prime}=14 \mathrm{kPa}$ ) 
are thought to protect it from cation exchange by physical encapsulation (Alther 1984) and prevent the collapse of the double-layers, which is associated with the increase in permeability of cation-exchanged bentonites.

\subsection{Permeability of overlap seams}

The permeability of GCLs has sometimes been described in terms of the parameter hydraulic permittivity $\psi\left(\mathrm{T}^{-1}\right)$ defined as (Heyer 1995)

$$
\psi=\frac{q}{\Delta h A}=\frac{k}{H}
$$

where $q$ is the volumetric flow rate $\left(\mathrm{L}^{3} / \mathrm{T}\right) ; \Delta h$ is head loss across the GCL (L); $A$ is the cross-sectional area of the GCL specimen $\left(\mathrm{L}^{2}\right), H$ is the GCL specimen thickness (L). The hydraulic permittivity is equal to the ratio between $k$ and the GCL thickness, and it is a useful parameter when $H$ is not known, such as when permeability tests are performed in flexible-wall permeameters not equipped with a device for measuring the specimen thickness.

In this study, to characterise the permeability of the overlap, the parameter hydraulic permittivity of the overlap, $\psi^{*}\left(\mathrm{~T}^{-1}\right)$ has been defined as

$$
\psi^{*}=\frac{q}{\Delta h\left(2 A_{\mathrm{L}}+A_{\mathrm{s}} / 2\right)}
$$

where $q$ is the measured volumetric flow rate $\left(\mathrm{L}^{3} / \mathrm{T}\right) ; \Delta h$ is the head loss across the overlap specimen set-up (L); $A_{\mathrm{S}}$ is the cross-sectional area of the overlap zone $\left(\mathrm{L}^{2}\right) ; A_{\mathrm{L}}$ is the cross-sectional area of the single-layer portion of the specimens $\left(\mathrm{L}^{2}\right)$ (Figure $3 \mathrm{~b}$ ). Due to the geometry of the overlap testing set-up (Figure $3 b$ ), even in case of perfect sealing (i.e. no interface flow), the seepage flow through the overlap is not, at rigour, one-dimensional. Assuming one-dimensional seepage flow and absence of preferential interface flow, the following theoretical relationship can be derived

$$
\psi^{*}=\frac{k_{\mathrm{ov}}}{H_{\mathrm{ov}}}
$$

where $k_{\mathrm{ov}}$ is the (vertical) hydraulic conductivity of each portion of the overlap (assumed equal) and $H_{\mathrm{ov}}$ is the thickness of each portion of the overlap (assumed equal). With the further assumption that, under the same confining effective stress, each portion of the overlap will have the same $k$ and the same $H$ of a single-layer specimen (i.e. $k=k_{\mathrm{ov}}$ and $H=H_{\mathrm{ov}}$ ), the following relationship can be obtained

$$
\psi^{*}=\psi=\frac{k}{H}
$$

Figure 8 displays the hydraulic permittivity values of the overlap $\left(\psi^{*}\right)$ and of a single-layer specimen $(\psi)$, permeated with DW and NSW, under an average isotropic effective stress of $14 \mathrm{kPa}$. In the case of water permeation, the values of $\psi$ and $\psi^{*}$ are practical coincident, in agreement with the theoretical prediction. The efficiency of the overlap is ensured by the swelling of DPH-GCL in the presence of pure water, which is also reflected by the

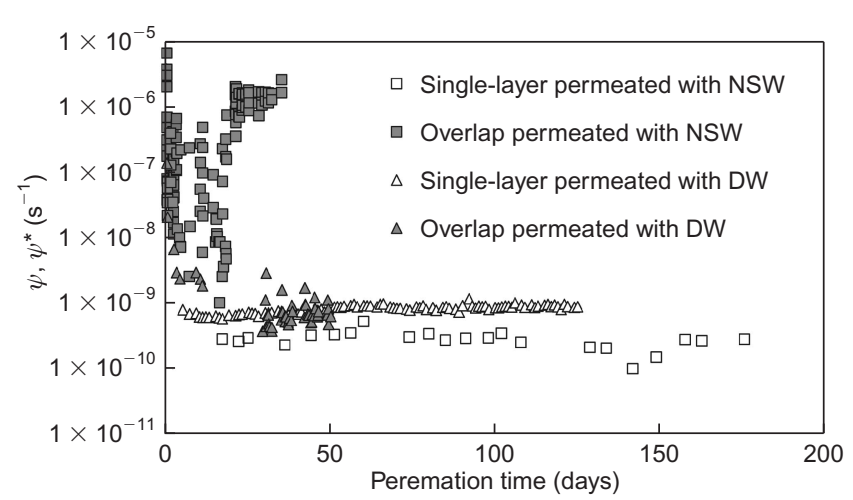

Figure 8. Hydraulic permittivity of the DPH-GCL single-layer $(\psi)$ and overlap seam $\left(\psi^{*}\right)$ permeated with DW and NSW (test in flexible-wall permeameter, $\sigma_{\mathrm{i}}^{\prime}=14 \mathrm{kPa}$ )

increase in specimen thickness during the tests. For example, the thickness of single-layers specimens permeated with DW increased from to 5.4 to $9.1 \mathrm{~mm}$ (average of two tests). The driving forces for further water adsorption and swelling are probably residual suction and osmotic gradients.

Using NSW as permeant liquid, hydraulic permittivity of the overlap $\psi^{*}$ stabilised on very high values $\left(\psi^{*}=2 \times 10^{-6} \mathrm{~s}^{-1}\right)$, of about four orders of magnitude higher than the hydraulic permittivity of the single-layer specimen permeated with NSW $\left(\psi=3 \times 10^{-10} \mathrm{~s}^{-1}\right)$. The high $\psi^{*}$ depends upon the lack of sealing of the overlap and the resulting preferential flow. The ionic strength of NSW inhibits the swelling of bentonite and hinders the sealing of the overlap. Inhibition of swelling was confirmed by the final thickness of the specimen permeated with NSW $(6.0 \mathrm{~mm})$, which was practically equal to the initial thickness $(5.4 \mathrm{~mm})$ despite the relatively low confining pressure of $14 \mathrm{kPa}$. Note that, at the same confining pressure, the $k$ of single-layer DPH-GCLs to NSW remained very low because it is not related to postinstallation swelling but rather to the material characteristics conferred by the manufacturing procedure.

To assess the impact of the confining stress on the hydraulic efficiency of the overlap, the effective confining pressure was increased by in steps to $110 \mathrm{kPa}$. For both tests a reduction in permittivity of about one order of magnitude was observed. However, the permittivity of the overlap specimen permeated with NSW remained high. A coloured dye was introduced in the permeant liquid during the last stage of permeation, under an effective stress of $110 \mathrm{kPa}$ (Figure 9). At the inspection of the specimen after the test, a preferential flow through the overlap interface was evident from the coloured paths (Figure 10)

Permeability tests were repeated on identically prepared overlap specimen except for bentonite paste spread on the overlap area (about $1 \mathrm{~mm}$ of bentonite paste on each side). The results were practically coincident for DW and NSW as permeant liquids (Figure 11). Note that in the case of DW the results with and without bentonite paste were also practically coincident. Therefore in applications were contact with NSW is possible, a performance equivalent to that observed with DW can be obtained by application of 


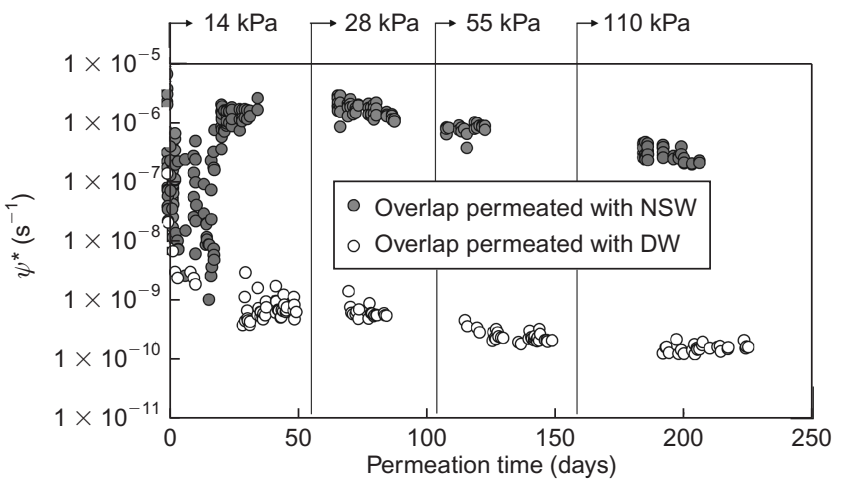

Figure 9. Hydraulic permittivity of DPH-GCL overlap seams $\left(\psi^{*}\right)$ permeated with DW and NSW under increasing effective stress

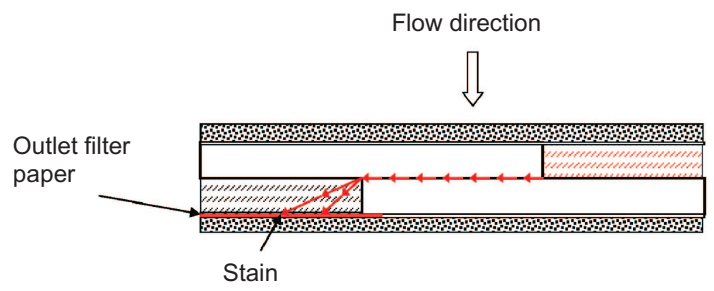

(a)

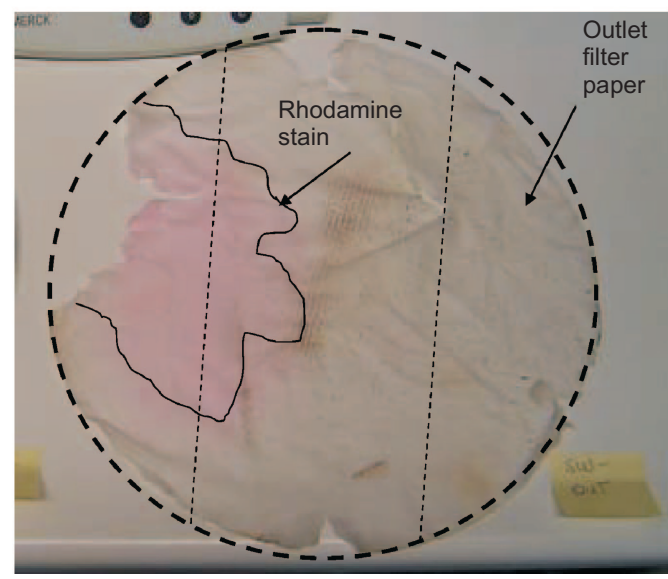

(b)

Figure 10. Test on the overlap permeated with NSW: (a) schematic of interface flow through the overlap during dye-assisted permeation with rhodamine; (b) picture of the outlet filter paper stained with rhodamine (note that the filter paper partly tore during disassembly of the apparatus)

bentonite paste on the overlap. Conversely, simple overlap seams (without bentonite paste) do not seem to be able to ensure a good performance in the presence of NSW, even at relatively high confining pressure. From a practical point of view, the need for bentonite paste in overlap seams causes an increase in costs and in installation times.

\section{CONCLUSIONS}

Dense prehydrated geosynthetic clay liners (DPH-GCLs) are a particular type of GCLs produced by a patented process in which the bentonite is prehydrated and then extruded under vacuum into a dense sheet. The most notable difference with conventional GCLs is that bento-

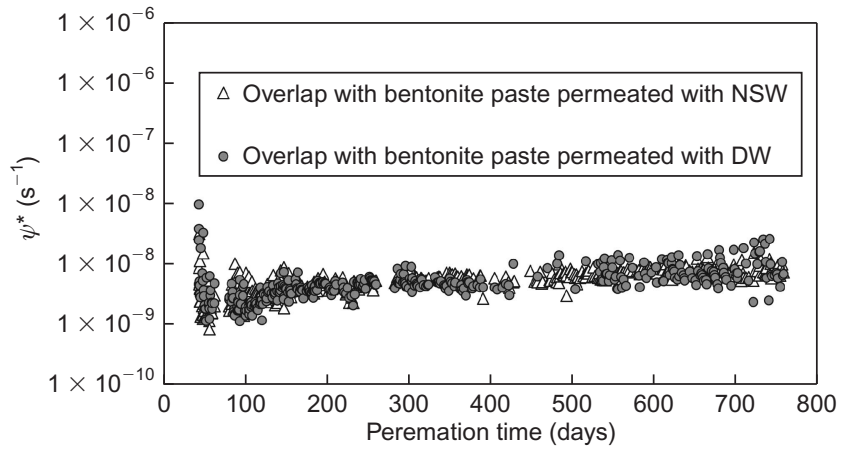

Figure 11. Hydraulic permittivity of DPH-GCL overlap $\left(\psi^{*}\right)$ with addition of bentonite paste permeated with $\mathrm{DW}$ and NSW (tests in flexible-wall permeamter, $\sigma_{\mathrm{i}}^{\prime}=14 \mathrm{kPa}$ )

nite is already hydrated at installation instead of becoming hydrated during the service life. The paper describes the results of permeability tests carried out using water, natural seawater (NSW) and a calcium solution to provide insight into the hydraulic performance of a DPH-GCL product.

The permeability tests on single-layer GCLs specimens were performed using flexible wall permeameters $0.10 \mathrm{~m}$ in diameter, whereas the permeability tests on the overlap of the DPH-GCL were performed using a flexible wall permeameter able to accommodate specimens $0.305 \mathrm{~m}$ in diameter. Test results showed that the DPH-GCL has very low permeability to water, with $k$ ranging from $8 \times 10^{-12}$ to $5 \times 10^{-13} \mathrm{~m} / \mathrm{s}$ with the confining stress ranging from 14 to $275 \mathrm{kPa}$. Permeation with a $12.5 \mathrm{mmol} / 1 \mathrm{Ca}^{2+}$ solution, which lasted more than 5 years, did not impact significantly on the permeability, unlike the results described in the literature for conventional GCLs subjected to similar conditions. The value of $k$ was found to be very low $\left(1.6 \times 10^{-12} \mathrm{~m} / \mathrm{s}\right)$ also in case of direct permeation NSW.

In addition to the low hydraulic conductivity of the GCL, the efficiency of the seams is crucial to the overall efficiency of the hydraulic barrier. According to the technical specifications, the seams of the DPH GCL product used in this study are obtained by overlapping the edges of adjacent panels for a minimum of $0.10 \mathrm{~m}$. This overlap is less than commonly specified for conventional GCLs $(0.15-0.30 \mathrm{~m})$. As this product is mainly recommended for waterproofing of below-ground structures, the specified minimum overlap probably accounts for the perception that risks of subgrade deformations and desiccation/shrinking are lower than in other applications (e.g. in landfill covers). Test results indicated that the hydraulic efficiency of the overlap seams strongly depends on the permeant liquid. When DW was used as permeant, bentonite swelling in the overlap prevented preferential flow and ensures sealing of the interface between the overlapped panels. Conversely, NSW inhibited the swelling of the bentonite and prevented the selfseaming mechanism of the overlap. Bentonite paste must be added to ensure sealing of the overlap in the presence of NSW. Therefore, when the permeant liquid to be 
contained is different than water it is necessary to carefully assess the need for bentonite paste at overlaps and pipe penetrations.

Although the available evidence on the hydraulic conductivity of DPH-GCLs, mostly based on laboratory tests, consistently showed that low permeability is usually preserved against strong electrolyte solutions, some important issues need to be further addressed for a complete understanding of the overall field performance over time. In particular, the main concerns are the risk of polymer decay or extraction to the surrounding environment and the consequent impact on the hydraulic performances, as well as the risk of desiccation for DPH-GCL products used in applications where desiccation is more likely to occur (e.g. artificial seasonal ponds, waste basins temporarily emptied for maintenance, lining applications with thin covers, landfill covers, landfill liners in case of heatproducing waste). Care should be also exercised in installations even on gentle slopes considering the absence of reinforcement in DPH-GCL products.

\section{ACKNOWLEDGEMENTS}

The DPH-GCL used in this study was kindly supplied to the authors by Ekos s.r.l., the former Italian distributor of Rawell Co. (UK). The opinions expressed in this paper are solely those of the authors and do not necessarily reflect those of the producers or distributors.

\section{NOTATION}

Basic SI units are given in parentheses

$A$ cross-sectional area of the GCL specimen $\left(\mathrm{m}^{2}\right)$

$A_{\mathrm{S}}$ cross-sectional area of the two-layer central portion of the overlap $\left(\mathrm{m}^{2}\right)$

$A_{\mathrm{L}}$ cross-sectional area of the single-layer lateral portions of the overlap $\left(\mathrm{m}^{2}\right)$

$H$ thickness of the GCL specimen (m)

$H_{\mathrm{ov}}$ thickness of each layer of the overlap (m)

$k$ hydraulic conductivity of the GCL $(\mathrm{m} / \mathrm{s})$

$k_{\mathrm{ov}}$ hydraulic conductivity of each layer of the overlap $(\mathrm{m} / \mathrm{s})$

$q$ volumetric flow rate $\left(\mathrm{m}^{3} / \mathrm{s}\right)$

$\Delta h$ head loss (m)

$\psi$ hydraulic permittivity of the GCL (1/s)

$\psi^{*}$ hydraulic permittivity of the overlap $(1 / \mathrm{s})$

\section{REFERENCES}

Alther, G. F. (1984). The function and effect of polymers in polymertreated bentonites. Bulletin of the Association of Engineering Geologists, 21, No. 1, 113-115.

ASTM D854 Standard Test Methods for Specific Gravity of Soil Solids by Water Pycnometer. ASTM International, West Conshohocken, PA, USA.

ASTM D2216 Standard Test Methods for Laboratory Determination of Water (Moisture) Content of Soil and Rock by Mass. ASTM International, West Conshohocken, PA, USA.

ASTM D5084 Standard Test Methods for Measurement of Hydraulic
Conductivity of Saturated Porous Materials Using a Flexible Wall Permeameter. ASTM International, West Conshohocken, PA, USA. ASTM D5890 Standard Test Method for Swell Index of Clay Mineral Component of Geosynthetic Clay Liners. ASTM International, West Conshohocken, PA, USA.

ASTM D5993 Standard Test Method for Measuring Mass Per Unit of Geosynthetic Clay Liners. ASTM International, West Conshohocken, PA, USA.

Babu, S. G. L., Sporer, H., Zanzinger, H. \& Gartung, E. (2001). Selfhealing properties of geosynthetic clay liners. Geosynthetics International, 8, No. 5, 461-470.

Benson, C. H., Oren, A. H. \& Gates, W. P. (2010). Hydraulic conductvitity of two geosynthetic clay liners permeated with a hyperalkaline solution. Geotextiles and Geomembranes, 28, No. 2, 206-218.

Benson, C. H., Thorstad, P., Jo, H. Y. \& Rock, S. (2007). Hydraulic performance of geosynthetic clay liners in a landfill final cover. Journal of Geotechnical and Geonvironmental Engineering, 133, No. 7, 814-827.

Bouazza, A. (2002). Geosynthetic clay liners. Geotextiles and Geomembranes, 20, No. 1, 3-17.

Bouazza, A. (2010). Geosynthetic lining in mining applications. Environmental Geotechnics for Sustainable Development, Datta, M., Srivastava, R. K., Ramana, G. V. and Shahu, J. T., Editors, Tata McGraw Hill, New Delhi, India, pp. 221-259.

Cazzuffi, D. \& Crippa, E. (2004). Behaviour vs. time of geosynthetic clay liners sampled from a brownfield in southern Italy after seven years of installation. Proceedings of $3 r d$ Asian Regional Conference on Geosynthetics, June, Seoul, Korea, pp. 411-418.

Di Emidio, G. (2010). Hydraulic and Chemico-osmotic Performance of Polymer-treated Clays, $\mathrm{PhD}$ dissertation, Ghent University, Belgium.

Egloffstein, T. (1995). Properties and test methods to assess bentonite used in GCLs. Geosynthetic Clay Liners. Proceedings of the International Symposium on Geosynthetic Clay Liners, April 1994, Nuremberg, Germany, Koerner, R., Gartung, E. and Zanziger, H., Editors, Balkema, Rotterdam, the Netherlands, pp. 51-73.

Egloffstein, T. A. (2001). Natural bentonites: influence of the ion exchange and partial desiccation on permeability and self-healing capacity of bentonites used in GCLs. Geotextiles and Geomembranes, 19, No. 7, 427-444.

Estornell, P. \& Daniel, D. E. (1992). Hydraulic conductivity of three geosynthetic clay liners. Journal of Geotechnical Engineering, 118, No. 10, 1593-1606.

Fleischer, P. \& Heibaum, M. (2008). Excavation of GCL lining (GBRC) in navigation canals and dykes after several years of service. Proceedings of the 4th European Conference on Geosynthetics, EuroGeo4, 7-10 September, Edinburgh, UK (CD-ROM).

Flynn, B. N. \& Carter, G. C. (1998). Waterproofing Material and Method of Fabrication Therefor US Patent no. 6537676.

Gates, W. P., Bouazza, A. \& Churchman, G. J. (2009). Bentonite clay keeps pollutants at bay. Elements, 5, No. 2, 105-110.

Giroud, J. P., Badu-Tweneboah, K. \& Soderman, K. L. (1997). Comparison of leachate flow through compacted clay and geosynthetic clay liners in landfill liner systems. Geosynthetics International, 4, No. 3-4, 391-431.

Heerten, G. \& Koerner, R. M. (2008). Cover systems for landfills and brownfields. Land Contamination \& Reclamation, 16, No. 4, 343356.

Heyer, D. (1995). Basic examination on the efficiency of GCLs. Geosynthetic Clay Liners. Proceedings of the International Symposium on Geosynthetic Clay Liners, Nuremberg, Germany, April 1994, Koerner, R., Gartung, E. and Zanziger, H, Editors, Balkema, Rotterdam, the Netherlands, pp. 101-111.

Hornsey, W. P., Scheirs, J., Gates, W. P. \& Bouazza, A. (2010). The impact of mining solutions/liquors on geosynthetics. Geotextiles and Geomembranes, 28, No. 2, 191-198.

Jo, H. Y., Katsumi, T., Benson, C. H. \& Edil, T. B. (2001). Hydraulic conductivity and swelling of non-prehydrated GCLs permeated with single species salt solutions. Journal of Geotechnical and Geoenvironmental Engineering, 127, No. 7, 557-567. 
Katsumi, T., Ishimori, H., Onikata, M. \& Fukagawa, R. (2008). Longterm barrier performance of modified bentonite materials against sodium and calcium permeant solutions. Geotextiles and Geomembranes, 26, No. 1, 14-30.

Koerner, R. M. \& Koerner, G. R. (2005a). GRI White Paper \#5. In Situ Separation of GCL Panels Beneath Exposed Geomembranes, Geosynthetic Institute, Folsom, PA, USA.

Koerner, R. M. \& Koerner, G. R. (2005b). In situ separation of GCL panels beneath exposed geomembranes. Geotechnical Fabrics Report, IFAI, Roseville, MN, USA, pp. 34-39.

Kolstad, D. C., Benson, C. H. \& Edil, T. B. (2004a). Hydraulic conductivity and swell of nonprehydrated geosynthtic clay liners permeated with multispecies inorganic solutions. Journal of Geotechnical and Geoenvironmental Engineering, 130, No. 12, 1236-1249.

Kolstad, D. C., Benson, C. H., Edil, T. B. \& Jo, H. Y. (2004b). Hydraulic conductivity of a dense prehydrated GCL permeated with aggressive inorganic solutions. Geosynthetics International, 11, No. 3, 233-241.

Lake, C. B. \& Rowe, R. K. (2000). Swelling characteristics of needlepunched, thermally treated geosynthetic clay liners. Geotextiles and Geomembranes, 18, No. 2-4, 72-101.

Lange, K., Rowe, R. K. \& Jamieson, H. (2007). Metal retention in geosynthetic clay liners following permeation by different mining solutions. Geosynthetics International, 14, No. 3, 178-187.

Li, H. M., Bathurst, R. J. \& Rowe, R. K. (2002). Use of GCLs to control hydrocarbons in severe environmental conditions. Clay Geosynthetic Barriers, Proceedings of International Symposium, April Nuremberg, Germany, Zanzinger, H., Koerner, R. M. and Gartung, E., Editors, Balkema, Lisse, the Netherlands, pp. 187-198.

Lin, L. C. \& Benson, C. H. (2000). Effect of wet-dry cycling on swelling and hydraulic conductivity of GCLs. Journal of Geotechnical and Geoenvironmental Engineering, 126, No. 1, 40-49.

Lo, I. M. C., Mak, R. K. M. \& Lee, S. C. H. (1997). Modified clays for waste containment and pollutant attenuation. Journal of Environmental Engineering, 123, No. 1, 25-32.

Malusis, M. A. \& McKeehan, D. (2013). Chemical compatibility of model soil-bentonite backfill containing multiswellable bentonite. Journal of Geotechnical and Geoenvironmental Engineering, 139, No. 2, 189-198.

Mazzieri, F. \& Pasqualini, E. (2000). Permeability of damaged geosynthetic clay liners. Geosynthetics International, 7, No. 2, 101-118.

Mazzieri, F. \& Pasqualini, E. (2008). Effect of dry/wet cycles and cation exchange on the permeability of a dense prehydrated GCL. Proceedings Eurogeo4 Fourth International Conference on Geosynthetics, Dixon, N., Editor, IGS UK Chapter, Loughborough, UK (CD-ROM).

Mazzieri, F., Pasqualini, E. \& Van Impe, W. F. (2000). Compatibility of GCLs with organic solutions. Proceedings of GeoEng 2000, Technomic Publishing, Melbourne, Australia, Vol. 2, pp. 251-256.

Mazzieri, F., Pasqualini, E., Di Emidio, G. \& Van Impe, W. F. (2009). Hydraulic conductivity of a dense prehydrated GCL subjected to partial desiccation. Proceedings of XVII ICSMGE, Hamza, M., Shanien, M. and El-Massalamy, Y., Editors, IOS Press, Amsterdam, the Netherlands, Vol. 1, pp. 885-888.

Mazzieri, F., Di Emidio, G., Fratalocchi, E., Di Sante, M. \& Pasqualini, E. (2013). Permeation of two GCLs with an acidic metal-rich synthetic leachate. Geotextiles and Geomembranes, 40, No. 5, 1-11.

McBride, M. (1994). Environmental Chemistry of Soils, Oxford University Press, New York, NY, USA, pp. 406.

McRory, J. A. \& Ashmawy, A. K. (2005). Polymer treating of bentonite clay for contaminant resistant barriers. GeoFrontiers 2005, Waste Containment and Remediation, Alshawabkeh, A., Benson, C. H.,
Culligan, P. J., Evans, J. C., Gross, B. A., Narejo, D., Reddy, K. R., Shackleford, C. D. and Zornberg, J. G., Editors, ASCE, Reston, VA, USA, GSP No. 142 (CD-ROM).

Meer, S. R. \& Benson, C. H. (2007). Hydraulic conductivity of geosynthetic clay liners exhumed from landfill final covers. Journal of Geotechnical and Geoenvironmental Engineering, 133, No. 5, $550-562$.

Mitchell, J. K. (1993). Fundamentals of Soil Behaviour, 2nd edition, Wiley, New York, NY, USA, pp. 456.

Onikata, M., Kondo, M. \& Kamon, M. (1996). Development and characterization of a multiswellable bentonite. Proceedings of the 2nd International Conference on Environmental Geotechnics, Kamon, M., Editor, Balkema, Rotterdam, the Netherlands, pp. 587590.

Petrov, R. J., Rowe, R. K. \& Quigley, R. M. (1997). Selected factors influencing GCL hydraulic conductivity. Journal of Geotechnical and Geoenvironmental Engineering, 123, No. 8, 683-695.

Qiu, H. \& Yu, J. (2008). Polyacrilate/carboxymethylcellulose modified montmorillonite superabsorbent nanocomposite: preparation and water absorbency. Journal of Applied Polymer Science, 107, No. 1, $118-123$.

Reither, P. \& Eichenauer, T. (2002). Application of a newly developed double lining system. Clay Geosynthetic Barriers, Proceedings of International Symposium, April, Nuremberg, Germany, Zanzinger, H., Koerner, R. M. and Gartung, E., Editors, Balkema, Lisse, the Netherlands, pp. 49-55.

Rowe, R. K., Bostwick, L. E. \& Thiel, R. (2010). Shrinkage characteristics of heat-tacked GCL seams. Geotextiles and Geomembranes, 28, No. 4, 352-359.

Sari, K. \& Chai, J. (2013). Self healing capacity of geosynthetic clay liners and influencing factors. Geotextiles and Geomembranes, 41, No. 1, 64-71.

Scalia, J. \& Benson, C. H. (2011). Hydraulic conductivity of geosynthetic clay liners exhumed from landfill final covers with composite barriers. Journal of Geotechnical and Geoenvironmental Engineering, 137, No. 1, 683-695.

Scalia, J., Benson, C. H., Edil, T. B., Bohnhoff, G. L. \& Shackelford, C. D. (2011). Geosynthetic clay liners containing bentonite polymer nanocomposite. Geo-Frontiers 2011, Advances in Geotechnical Engineering, Han, J. and Alzamora, D. E., Editors, Reston, VA, USA, GSP No. 211, pp. 2001-2009.

Schroeder, C., Monjoie, A., Illing, P., Dosquet, D. \& Thorez, J. (2001). Testing a factory-prehydrated GCL under several conditions. Proceedings of Sardinia 2001, October, CISA, Cagliari, Italy, pp. 188-196.

Shackelford, C. D., Benson, C. H., Katsumi, T., Edil, T. B. \& Lin, L. (2000). Evaluating the hydraulic conductivity of GCLs permeated with non-standard liquids. Geotextiles and Geomembranes, 18, No. 2, 133-161.

Shackelford, C. D., Sevick, G. W. \& Eykholt, G. R. (2010). Hydraulic conductivity of geosynthetic clay liners to tailings impoundment solutions. Geotextiles and Geomembranes, 28, No. 2, 149-162.

Shan, H. \& Lai, Y. (2002). Effect of hydrating liquid on the hydraulic properties of geosynthetic clay liners. Geotextiles and Geomemembranes, 20, No. 1, 19-38.

Thiel, R. \& Richardson, G. (2005). Concern for GCL Shrinkage when Installed on Slopes, GRI-18 at GeoFrontiers, GI Publications, Folsom, PA, USA, paper 231.

Thiel, R., Giroud, J. P., Erickson, R., Criley, K. \& Bryk, J. (2006). Laboratory measurements of GCL shrinkage under cyclic changes in temperature and hydration conditions. Proceedings of the 8th International Conference on Geosynthetics, Yokohama, Japan, Millpress, London, UK, Vol. 1, pp. 21-44.

The Editor welcomes discussion on all papers published in Geosynthetics International. Please email your contribution to discussion@geosynthetics-international.com by 15 August 2015. 